\title{
The effects of land use on soil moisture variation in the Danangou catchment of the Loess Plateau, China
}

\author{
Bojie $\mathrm{Fu}^{\mathrm{a}, *}$, Jun Wang ${ }^{\mathrm{b}}$, Liding Chen ${ }^{\mathrm{a}}$, Yang Qiu ${ }^{\mathrm{c}}$ \\ ${ }^{a}$ Department of Systems Ecology, Research Center for Eco-Environmental Sciences, \\ Chinese Academy of Sciences, P.O. BOX 2871, Beijing 100085, China \\ b Land Consolidation and Rehabilitation Center, Ministry of Land and Resources, Beijing 100035, China \\ ${ }^{\mathrm{c}}$ Department of Resources and Environmental Science, Beijing Normal University, Beijing 100875, China
}

\begin{abstract}
Soil moisture plays a critical role in both crop growth and vegetation restoration in semiarid environments. Its spatial and temporal variability results from topography, soils, vegetation and land uses. However, little knowledge exists about the effects of land use structure on soil moisture variability. In order to analyze soil moisture variations in relation to land use patterns, five land use structures and seven land use types were selected to monitor soil moisture. Soil moisture measurements were performed biweekly at 26 locations in a small catchment on the Loess Plateau of China from May to October 1998. The measurements were taken using a Theta-Probe at five depths of soil profile $(0-5,15-20,25-30,45-50$ and $70-75 \mathrm{~cm})$. These data were analyzed for soil moisture variations in space and time for seven land use types. Three peaks and three troughs of soil moisture variations during the growing season were found. The influence of shrubland on mean soil moisture within $0-70 \mathrm{~cm}$ was significantly different from that of cropland, orchard and intercropping land. Three types of soil moisture changes in profile were classified as increasing, decreasing and waving types. An analysis of the differences in soil moisture for five land use structures indicated that the influences of land use patterns on soil moisture were complex. This study provides an insight into the implications for hydrological modeling, runoff and erosion control in this area.
\end{abstract}

(C) 2003 Elsevier Science B.V. All rights reserved.

Keywords: Soil moisture variation; Land use structure; Runoff and erosion control; Loess Plateau of China

* Corresponding author. Fax: +86-10-62923563.

E-mail address: bfu@mail.rcees.ac.cn (B. Fu). 


\section{Introduction}

Soil moisture plays a critical role in crop growth and vegetation restoration in semiarid environments, and is also an important factor for hydrological modeling. However, soil moisture exhibits a tremendous heterogeneity in space and time even in small catchments (Gomez-Plaza et al., 2000). This variability of soil moisture results from the differences in topography (Burt and Butcher, 1985), soils (Hawley et al., 1983), vegetation (Le Roux et al., 1995) and land uses (Fu et al., 2000). A better understanding of the soil moisture variability is important for improving hydrological models (Grayson et al., 1992; Stolte et al., 2003) and land management in runoff and erosion control (Fitzjohn et al., 1998). Many have studied soil moisture variability for evaluating the factors of controlling soil moisture, determining their significance in the ecosystem processes and predicting soil moisture in catchment or on a large scale (e.g. Anderson and Kneale, 1980; Sala et al., 1992; Bárdossy and Lehmann, 1998; Qiu et al., 2001; Qiu et al., 2003). However, little attention is paid to the influences of land use patterns on soil moisture. Evaluating the effects of land use and its pattern on soil moisture is difficult because the differences in land uses which produce a change in the soil properties and evapotranspiration are likely to increase soil moisture variability across the landscape (Andrew et al., 1998; Wang et al., 2001). Vachaud et al. (1985) asserted that soil texture was the main factor that controlled soil moisture, but in semiarid areas, other factors, such as topography, vegetation and land use, may have a major influence on soil water content (Grayson and Western, 1998). The Loess Plateau of China has the highest rate of erosion in the world. One of the reasons for soil erosion is immoderate land use ( $\mathrm{Fu}$, 1989; Fu and Gulinck, 1994). Because land uses can give rise to variations in soil physical and hydrological properties in relation to soil moisture, the creation of a mosaic pattern of land use may be advantageous in runoff and erosion control in this region. The objective of this paper is to analyze the relationships between land use and soil moisture by means of intensive monitoring in space and time. In particular, our work focused on the following aspects:

(1) To determine temporal variations of soil moisture for seven land uses,

(2) To analyze differences in profile soil moisture for seven land uses,

(3) To study the spatial variations of soil moisture for five land use structures.

\section{Materials and methods}

\subsection{Study area}

The Danangou catchment $\left(36^{\circ} 53^{\prime} \mathrm{N}, 109^{\circ} 17^{\prime} \mathrm{E}\right)$ is situated on the middle part of the Loess Plateau in northern Shaanxi province in China. The catchment has an area of 3.5 $\mathrm{km}^{2}$ and an altitude between 1000 and $1350 \mathrm{~m}$. The region has a semiarid continental climate with an average annual temperature of $8.8{ }^{\circ} \mathrm{C}$. Monthly mean temperatures range from $22.5{ }^{\circ} \mathrm{C}$ in July to $-7{ }^{\circ} \mathrm{C}$ in January. The average annual precipitation is $562 \mathrm{~mm}$ with great interannual variability and $60 \%$ of the rainfall falls between July and September. 
The active moisture changes occur in deeper layers due to the relatively high permeability of this soil. Thus, from a runoff process perspective, the soil moisture in the deeper layers also has an important significance. Soil of the study area developed on wind-deposited loess parent material in the catchment (Messing et al., 2003). The most common soil is loess with silt ranging from $64 \%$ to $73 \%$ and clay varying from $17 \%$ to $20 \%$ (Table 1 ). The soil is weakly resistant to erosion and its erosion rate was large at about $10-12 \mathrm{~kg} / \mathrm{m}^{2} /$ year (Song et al., 1989; Wang et al., 2003).

Due to long-term human activity, natural vegetation has been destroyed and changed into cropland (Chen et al., 2001). Current land uses were slope cropland, woodland, grassland, shrubland, orchard, fallow land and intercropping land which were investigated. Crops were mainly potatoes (Solanum tuberosum), beans (Phaseolus valgaris), maize (Zea mays L.) and millet (Panicum miliaceum). The forest and artificial woods was dominated by locust trees (Robinia pseudoacacia L.). The grassland was mainly covered by annuals such as sweet wormwood (Artemisia annua L.), annual fleabane (Erigeron annuus Pers.) and sandy needlegrass (Stipa glareosa p. Smirn). Littleleaf peashrub (Caragana microphylla) and apple trees (Malus pumila mill) existed on the shrubland and orchard, respectively. The fallow land slowly came into being 2 and 3 years later when cultivated plots were abandoned. There were crops and apple trees on the intercropping land.

\subsection{Methods}

Five typical land use structures including 26 sample points were selected for measuring soil moisture content. These structures from the top to foot of the hillslope were: cropland-cropland-cropland (T1), fallow land-cropland-woodland-orchard (T2), fallow land-grassland-cropland (T3), fallow land-shrubland-intercropping land (terrace)woodland (T4) and fallow land-shrubland-cropland (terrace)-orchard (T5) (see Fig. 1).

Soil moisture was measured using a Theta-Probe Soil Moisture Sensor Type ML1 (Delta-T Devices, Eijkelkamp Agrisearch Equipment, The Netherlands). Soil moisture data were obtained on 10 occasions from May to October 1998 at approximately biweekly intervals. After augering to the measuring depth, four parallel steel rods (length $6 \mathrm{~cm}$, diameter $0.3 \mathrm{~cm}$, and spacing $2.5-3 \mathrm{~cm}$ ) were inserted vertically into the soil, and

Table 1

Soil particle size distribution and bulk density in seven land use types

\begin{tabular}{llllll}
\hline Land use type & $\begin{array}{l}2-0.05 \mathrm{~mm} \\
\text { Sand (\%) }\end{array}$ & $\begin{array}{l}0.05-0.002 \mathrm{~mm} \\
\text { Silt (\%) }\end{array}$ & $\begin{array}{l}<0.002 \mathrm{~mm} \\
\text { Clay }(\%)\end{array}$ & $\begin{array}{l}\text { Ratio } \\
(\mathrm{sand} / \mathrm{clay}) \\
(\%)\end{array}$ & $\begin{array}{l}\text { Bulk density } \\
\left(\mathrm{g} / \mathrm{cm}^{3}\right)\end{array}$ \\
\hline Cropland & 14.80 & 65.62 & 19.58 & 75.59 & 1.28 \\
Fallow land & 13.44 & 67.73 & 18.84 & 71.34 & 1.25 \\
Grassland & 16.35 & 64.78 & 18.88 & 86.60 & 1.22 \\
Woodland & 10.79 & 70.79 & 18.43 & 58.55 & 1.25 \\
Orchard & 10.25 & 72.10 & 17.65 & 58.07 & 1.27 \\
Intercropping land & 13.50 & 68.57 & 17.93 & 75.29 & 1.21 \\
Shrubland & 13.70 & 69.13 & 17.17 & 79.79 & 1.24 \\
\hline
\end{tabular}




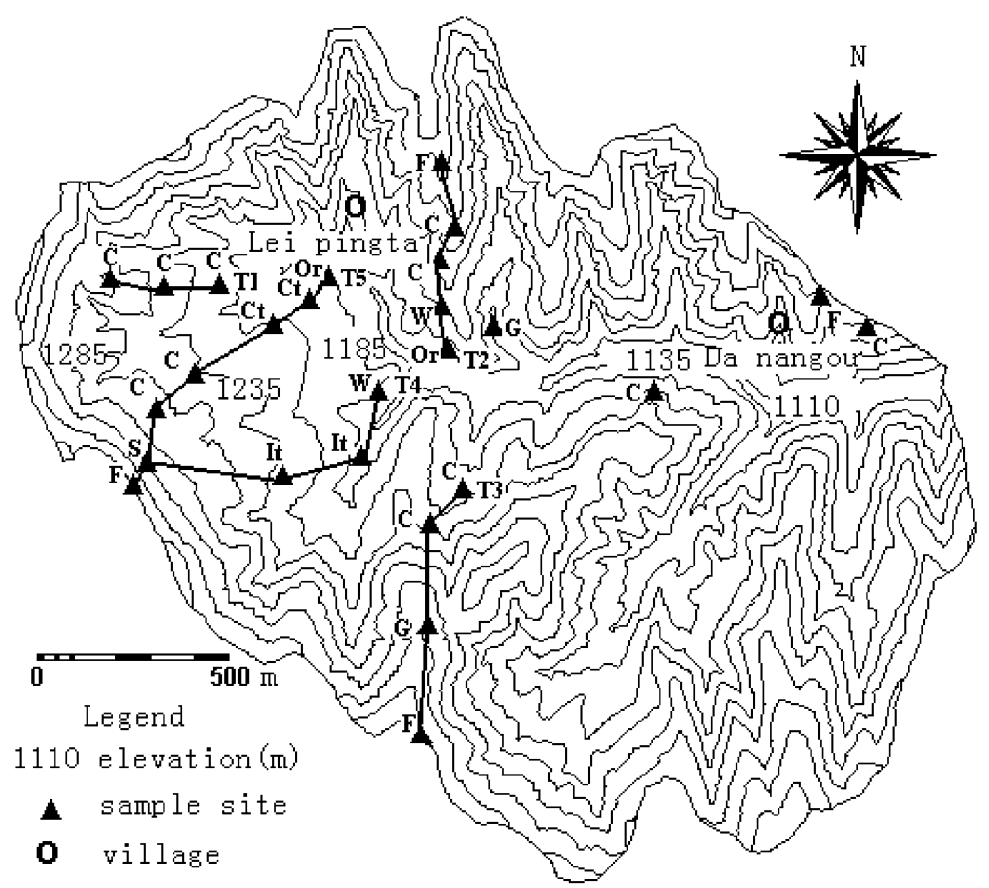

Fig. 1. The spatial distribution of sample sites in the Danangou catchment (T1, T2, T3, T4 and T5-Land use structure 1, 2, 3, 4 and 5. C-Cropland, F-Fallow land, G-Grassland, W-Woodland, Or-Orchard, ItIntercropping land, $\mathrm{S}$ - Shrubland, and $\mathrm{Ct}$-Terrace cropland).

remained in position until the displayed value of the Theta-Probe stabilized. Owing to the destructive nature of the soil auger method, five random locations within a 2-m circle around each sample point were taken to measure moisture content at five depths: $0-5,15-$ $20,25-30,45-50$ and $70-75 \mathrm{~cm}$. The mean moisture content for five locations was computed as the soil moisture level of each sample site. Rainfall, a total of $465.42 \mathrm{~mm}$ during the study period, was recorded by an automatic data-logged rain gauge located in the catchment.

Soil samples for determining particle size distribution were collected according to horizons at soil profiles. Particle sizes were measured using traditional sieving methods to quantify the coarse grains (gravel) and then using the hydrometer method to determine the particle fractions. The bulk density $\left(\mathrm{g} / \mathrm{cm}^{3}\right)$ for $20-25 \mathrm{~cm}$ depth of each sites using ring (diameter $5 \mathrm{~cm}$ and height $5 \mathrm{~cm}$ ) was computed as the ratio of the mass of dry soil $(\mathrm{g})$ to the volume of the sample $\left(\mathrm{cm}^{3}\right)$ (Editorial Committee, 1996).

Statistical analyses were performed to test the influence of land use on soil moisture using one-way ANOVA, and multiple comparisons were made using the least significant difference (LSD) method. These analyses were conducted through SPSS program (SPSS, 1993). 


\section{Results}

\subsection{Temporal variations of soil moisture in seven land uses}

\subsubsection{Temporal variations of mean soil moisture within $0-70 \mathrm{~cm}$}

The temporal variations of mean soil moisture content within $0-70 \mathrm{~cm}$ in seven land uses are shown in Fig. 2. Also shown are the daily rainfall and the variance over time. The seasonal changes in the mean soil moisture were apparent. First, as expected, an increase and decrease in soil moisture corresponded to high and low rainfall, and it exhibited three peaks and three troughs (Fig. 2). Second, the mean moisture content reached a peak following a heavy rain event (on 20 and 21 May) and decreased thereafter. Moreover, a "dry" sequence appeared. Although several small rain events occurred between 30 May and 1 July, they did not interrupt the dry trend.

In general, the moisture content reaching peak value corresponded to the amount of precipitation, with higher mean moisture contents appearing after heavier rain. However, there were differences in response to the rain due to land uses. For example, the peak in mean moisture content for woodland and intercropping land showed a lag effect following a rain event (Fig. 2). The main reason may be the interception by tree crown
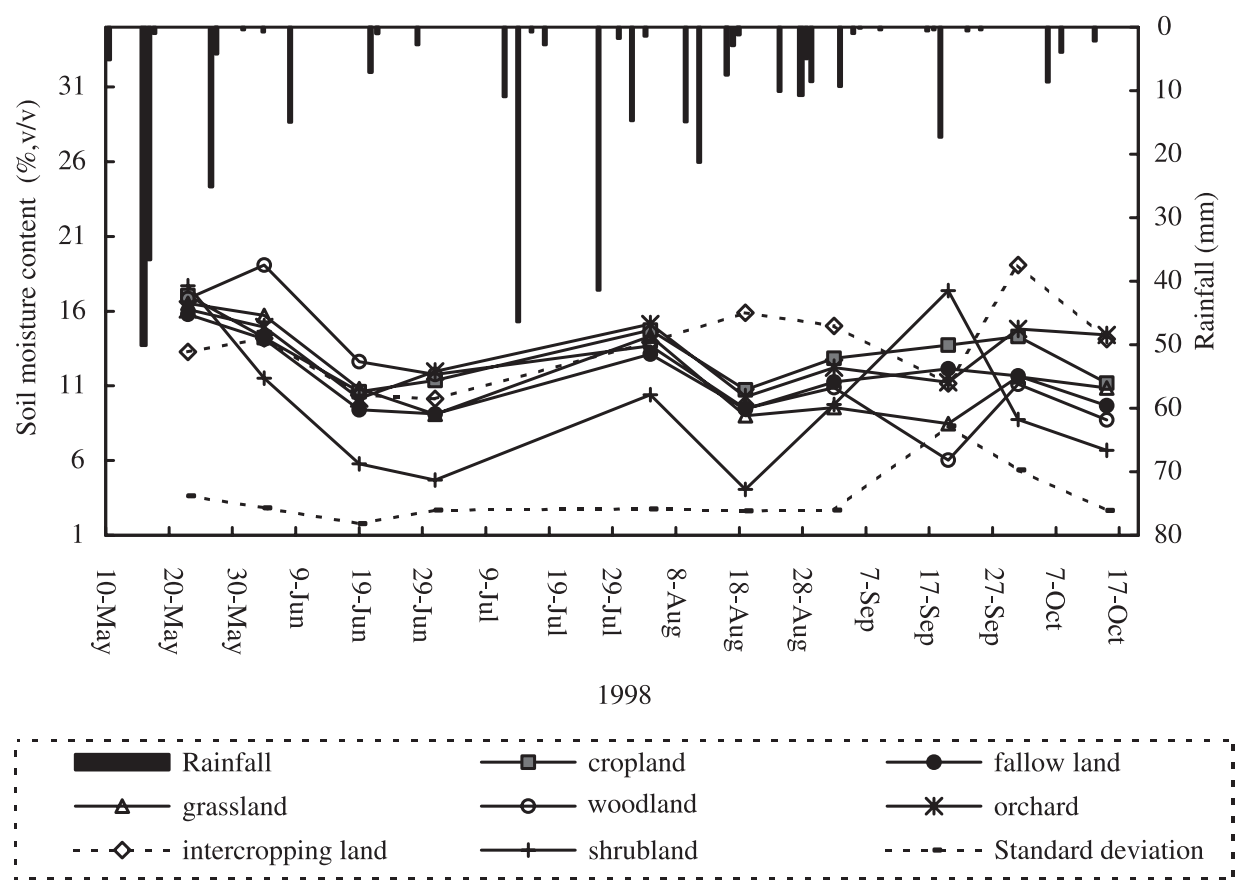

Fig. 2. Temporal variations of mean soil moisture within $0-70 \mathrm{~cm}$ in seven land uses. Also shown is standard deviation value $(\%)$ and daily rainfall $(\mathrm{mm})$. 
and the buffering influence of groundcover. Also, the differences in soil physical properties such as particle distribution and bulk density (Table 1) may contribute to the difference. Furthermore, the mean soil moisture in shrubland was lower than that in other land uses from 4 June to 2 September and between 1 and 15 October. There is more likely due to the fact that $C$. microphylla has deep and enormous roots for soil water intake to survive in dry environments (Wang and Li, 1989). The ANOVA results indicated that the influences of land use on soil moisture were significant under $\alpha=0.1$ level. And multiple comparisons indicated that the impact of shrubland on mean moisture was significantly difference between the cropland, orchard and intercropping land (Table 2).

The temporal changes of soil moisture variance for 26 sampling points were described in Fig. 2. The spring and summer months experienced more frequent rain events so that the mean moisture content was relatively similar before 19 August. As a result, the variance exhibited a low level. Compared with previous months, the variability was evident during September and October. Moreover, it was found that if a moderate rain event occurred it might result in higher variability under dry conditions (Fig. 2). This result was not consistent with previous findings that heavier rains and higher mean moisture content were often associated with higher variability (Bell et al., 1980; Famiglietti et al., 1998). A possible explanation is that land use reported by them is uniform, whereas we examine multiple land uses in our study. An alternative explanation is that surface soil moisture is studied in their papers, but not in our study.

\subsubsection{Temporal variations of profile soil moisture}

The temporal variations of profile soil moisture for seven land uses are shown in Table 3. The results indicated that standard deviation (S.D.) of soil moisture within upper layers $(5,15,25 \mathrm{~cm})$ exhibited high levels as reported by many authors (e.g. Anderson and Burt, 1978; Barling et al., 1994; Wang et al., 2001). However, the soil moisture variations in deeper layers were relatively stable with seasonal changes and greatly influenced by land use. For example, the moisture variance under the cropland, fallow land and shrubland decreased with depth (Table 3), but fluctuation under the other land uses.

Table 2

Multiple comparisons for mean soil moisture content of seven land use types during observation period

\begin{tabular}{ll}
\hline Land use type & Mean soil moisture content $(\%, \mathrm{v} / \mathrm{v})$ \\
\hline Cropland & $13.08 \mathrm{~b}$ \\
Fallow land & $11.57 \mathrm{ab}$ \\
Grassland & $11.60 \mathrm{ab}$ \\
Woodland & $12.02 \mathrm{ab}$ \\
Orchard & $13.12 \mathrm{~b}$ \\
Intercropping land & $13.71 \mathrm{~b}$ \\
Shrubland & $9.67 \mathrm{a}$ \\
\hline
\end{tabular}

Values in each column with the same letter are not significantly $(P<0.05$, LSD) different among land uses. 
The cropland, fallow land and shrubland shared the same characteristics in soil moisture variance with depth. Soil moisture content under the cropland and fallow land increased with depth. However, soil moisture exhibited a decreasing trend with depth except for $5 \mathrm{~cm}$ between 4 August and 15 October in the shrubland (Table 3). In addition, soil moisture content within $70 \mathrm{~cm}$ in the woodland reached a peak value $(23.12 \%)$ on 4 June and later gradually decreased. However, the soil water content in the orchard peaked at a value of $15.88 \%$ within $70 \mathrm{~cm}$ on 4 June and did not show a clearly decreasing trend thereafter (Table 3). Rainfall and the difference in distribution of roots may contribute to this difference.

\subsection{Profile variations of soil moisture in different land uses}

Fig. 3 provides the profile variations of soil moisture for seven land uses. Three types, increasing, decreasing and waving types, are classified based on soil moisture changes with depth. The increasing type included the cropland, fallow land, intercropping land and grassland. Soil moisture content at $5 \mathrm{~cm}$ was $8.6 \%$ in the fallow land, $10.25 \%$ in the cropland, $10.23 \%$ in the intercropping land and $10.45 \%$ in the grassland. Similarity in soil moisture with depth for the fallow land and cropland almost exhibited two parallel curves in Fig. 3. One possible explanation is that the fallow land had similar soil physical properties to cropland (Table 1). Soil moisture content in the intercropping land gradually increased with depth from $10.23 \%$ at $5 \mathrm{~cm}$ to $11.08 \%$ at $15 \mathrm{~cm}$, and then came to $17.6 \%$ at $70 \mathrm{~cm}$. This revealed reciprocal advantages of intercropping system for improving soil moisture (Kiepe, 1995). Soil moisture content in the grassland increased over a relatively small range with depth (Fig. 4). The waving type consisted of the woodland and orchard where soil moisture presented a high-low-high-low-high changes in profile. There are two potential explanations. First, the effects of the root distribution on soil moisture may contribute to this difference (Sala et al., 1992). Second, woods possibly transform the soil physical properties such as soil bulk density, physical composition and porosity (Zhu, 1993; José et al., 1995). These changes, in turn, influence the infiltration rate, storage and redistribution of soil water (Jiang, 1997; Kang et al., 1996). The decreasing type included only shrubland. Soil moisture reduced from $11.26 \%$ at $5 \mathrm{~cm}$ to $8.01 \%$ at $70 \mathrm{~cm}$.

\subsection{Variations of soil moisture in five land use structures}

Fig. 4 shows changes in the mean soil moisture content for five land use structures. Soil moisture presented a stable increase from the top to foot of hillslope on single land use structure (Fig. 4, T1). Anderson and Kneale (1980) and Knapp et al. (1993) observed a similar pattern. The mean soil moisture content was $10.92 \%$ in this land use structure. However, in the land use structure of fallow land-cropland-woodlandorchard, soil moisture contents in upper slope for the fallow land, cropland and downslope for orchard were higher than that in middle slope for the woodland (Fig. 4, T2). They were $12.89 \%$ in the fallow land, $12.97 \%$ in the cropland, $10.57 \%$ in the orchard and $7.07 \%$ in the woodland. Lower mean soil moisture in the woodland may be due to relative higher potential evapotranspiration than that in the fallow land, 
Table 3

Temporal variations of soil moisture for profile in seven land use types

\begin{tabular}{|c|c|c|c|c|c|c|c|c|c|c|c|c|}
\hline \multirow[t]{2}{*}{ Land use } & \multirow[t]{2}{*}{$\begin{array}{l}\text { Depth } \\
(\mathrm{cm})\end{array}$} & $\begin{array}{l}23 \text { May } \\
1998\end{array}$ & $\begin{array}{l}\text { 4 June } \\
1998\end{array}$ & $\begin{array}{l}19 \text { June } \\
1998\end{array}$ & $\begin{array}{l}1 \text { July } \\
1998\end{array}$ & $\begin{array}{l}4 \text { August } \\
1998\end{array}$ & $\begin{array}{l}19 \text { August } \\
1998\end{array}$ & $\begin{array}{l}30 \text { August } \\
1998\end{array}$ & $\begin{array}{l}15 \text { September } \\
1998\end{array}$ & $\begin{array}{l}1 \text { October } \\
1998\end{array}$ & $\begin{array}{l}15 \text { October } \\
1998\end{array}$ & S.D. \\
\hline & & \multicolumn{11}{|c|}{ Soil moisture content $(\%, \mathrm{v} / \mathrm{v})$} \\
\hline \multirow[t]{5}{*}{ Cropland } & 5 & 14.81 & 11.71 & 5.03 & 8.61 & 12.95 & 6.45 & 11.43 & 11.01 & 11.38 & 9.07 & 2.97 \\
\hline & 15 & 15.49 & 12.04 & 7.91 & 9.15 & 14.24 & 9.19 & 12.76 & 13.90 & 13.57 & 10.50 & 2.55 \\
\hline & 25 & 16.89 & 13.59 & 10.71 & 10.42 & 14.82 & 11.02 & 12.59 & 14.73 & 14.78 & 11.31 & 2.20 \\
\hline & 45 & 19.07 & 15.94 & 13.58 & 12.74 & 15.11 & 13.05 & 13.08 & 13.83 & 14.59 & 12.08 & 2.04 \\
\hline & 70 & 19.00 & 17.85 & 15.82 & 15.83 & 16.49 & 13.99 & 14.40 & 15.17 & 17.16 & 12.99 & 1.83 \\
\hline \multirow[t]{5}{*}{ Fallow land } & 5 & 13.35 & 12.01 & 4.62 & 6.30 & 11.51 & 4.54 & 8.34 & 9.47 & 8.33 & 7.56 & 3.02 \\
\hline & 15 & 15.18 & 12.31 & 7.35 & 6.53 & 12.88 & 7.44 & 10.52 & 10.02 & 10.84 & 8.45 & 2.77 \\
\hline & 25 & 16.45 & 13.79 & 9.22 & 8.18 & 13.48 & 9.55 & 11.57 & 11.01 & 12.87 & 9.46 & 2.58 \\
\hline & 45 & 17.09 & 15.81 & 11.91 & 10.37 & 14.25 & 12.11 & 12.81 & 14.61 & 12.99 & 9.91 & 2.28 \\
\hline & 70 & 16.86 & 16.70 & 13.87 & 14.28 & 13.43 & 13.58 & 13.07 & 15.63 & 13.29 & 12.99 & 1.48 \\
\hline \multirow[t]{5}{*}{ Grassland } & 5 & 16.73 & 17.49 & 8.70 & 7.54 & 15.61 & 6.23 & 7.41 & 4.15 & 9.67 & 10.97 & 4.65 \\
\hline & 15 & 17.30 & 15.70 & 8.02 & 6.74 & 15.74 & 8.28 & 8.99 & 5.61 & 10.84 & 10.63 & 4.10 \\
\hline & 25 & 16.15 & 15.51 & 9.63 & 7.69 & 14.30 & 9.32 & 8.59 & 7.55 & 11.95 & 10.87 & 3.19 \\
\hline & 45 & 15.99 & 15.14 & 11.80 & 11.31 & 13.68 & 11.31 & 11.25 & 10.04 & 12.22 & 11.20 & 1.92 \\
\hline & 70 & 16.31 & 14.75 & 15.90 & 12.23 & 12.36 & 9.80 & 11.45 & 14.95 & 13.43 & 10.67 & 2.24 \\
\hline
\end{tabular}




\begin{tabular}{|c|c|c|c|c|c|c|c|c|c|c|c|c|}
\hline \multirow[t]{5}{*}{ Woodland } & 5 & 17.26 & 18.62 & 9.03 & 12.96 & 14.62 & 8.72 & 11.93 & 5.34 & 13.98 & 9.56 & 4.12 \\
\hline & 15 & 16.56 & 16.89 & 10.82 & 7.05 & 14.71 & 8.85 & 10.73 & 5.27 & 11.25 & 9.09 & 3.89 \\
\hline & 25 & 15.99 & 17.63 & 11.59 & 10.26 & 13.72 & 10.00 & 11.33 & 6.09 & 11.85 & 8.57 & 3.40 \\
\hline & 45 & 16.93 & 19.16 & 11.21 & 14.12 & 12.23 & 10.45 & 10.45 & 5.56 & 11.80 & 8.29 & 3.96 \\
\hline & 70 & 17.51 & 23.12 & 20.44 & 14.46 & 13.10 & 9.39 & 10.01 & 7.95 & 6.67 & 8.03 & 5.70 \\
\hline \multirow[t]{5}{*}{ Orchard } & 5 & 16.34 & 14.77 & 6.86 & 12.33 & 18.27 & 8.98 & 14.06 & 7.08 & 15.62 & 13.12 & 3.93 \\
\hline & 15 & 16.30 & 13.87 & 8.27 & 9.95 & 17.41 & 8.52 & 13.52 & 8.58 & 15.53 & 12.97 & 3.44 \\
\hline & 25 & 17.21 & 14.89 & 10.51 & 11.12 & 14.61 & 10.69 & 12.70 & 10.06 & 16.83 & 14.64 & 2.67 \\
\hline & 45 & 16.67 & 15.33 & 11.25 & 12.20 & 12.17 & 11.93 & 10.52 & 12.74 & 14.50 & 14.96 & 2.01 \\
\hline & 70 & 14.06 & 15.88 & 13.92 & 14.17 & 13.24 & 11.12 & 10.32 & 17.70 & 11.56 & 16.34 & 2.38 \\
\hline \multirow[t]{5}{*}{ Intercropping land } & 5 & 10.46 & 12.69 & 7.23 & 7.96 & 11.70 & 10.46 & 8.34 & 7.74 & 15.95 & 9.79 & 2.69 \\
\hline & 15 & 11.29 & 12.28 & 7.05 & 6.90 & 13.59 & 10.54 & 11.95 & 8.20 & 17.44 & 11.53 & 3.19 \\
\hline & 25 & 11.37 & 14.34 & 10.08 & 9.14 & 14.25 & 16.83 & 15.00 & 11.29 & 23.47 & 13.23 & 4.12 \\
\hline & 45 & 15.41 & 14.83 & 13.40 & 11.70 & 15.00 & 19.99 & 18.13 & 12.11 & 20.80 & 16.12 & 3.09 \\
\hline & 70 & 17.88 & 16.73 & 14.17 & 14.91 & 15.08 & 21.59 & 21.59 & 16.40 & 17.72 & 20.02 & 2.69 \\
\hline \multirow[t]{5}{*}{ Shrubland } & 5 & 18.54 & 8.90 & 2.25 & 5.01 & 12.52 & 4.33 & 17.11 & 22.41 & 12.11 & 9.44 & 6.59 \\
\hline & 15 & 17.72 & 10.71 & 4.69 & 4.03 & 11.12 & 4.86 & 9.60 & 21.39 & 12.77 & 8.01 & 5.68 \\
\hline & 25 & 17.88 & 10.96 & 5.27 & 4.20 & 10.87 & 3.79 & 7.74 & 19.00 & 13.43 & 6.11 & 5.49 \\
\hline & 45 & 18.05 & 12.69 & 7.00 & 4.49 & 8.90 & 4.03 & 7.28 & 14.29 & 4.12 & 5.78 & 4.81 \\
\hline & 70 & 16.31 & 14.34 & 9.64 & 5.76 & 8.57 & 3.29 & 7.00 & 9.72 & 1.31 & 4.12 & 4.75 \\
\hline Rainfall (mm) & & 114.82 & 29.452 & 15.721 & 10.945 & 59.302 & 47.163 & 43.78 & 19.104 & 0.985 & 15.127 & \\
\hline
\end{tabular}




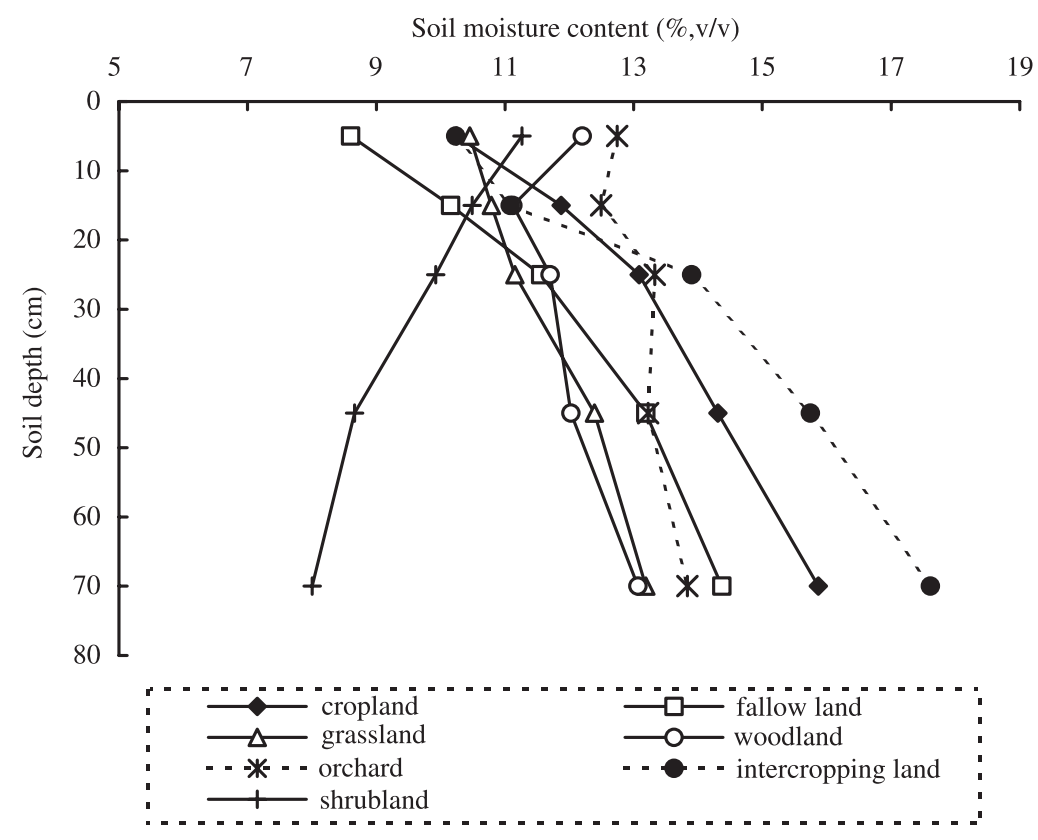

Fig. 3. Profile variations of mean soil moisture in seven land uses.

cropland and orchard. Although the soil moisture variations of fallow land-grasslandcropland (T3) showed a high-low-high trend from the top to foot of hillslope, $11.09 \%$ for the fallow land, $10.82 \%$ for the grassland and $11.1 \%$ for the cropland, it was almost uniform across the slope (Fig. 4, T3). Soil moisture correlated with slope degree and position (Ried, 1973). For the fallow land and cropland on gentle slope at the top and foot part of hill slopes, their soil water contents were relatively high. Due to grassland on steep slope in the middle part of the slope, this resulted in less water infiltrating into the soil, and soil moisture content in the grassland was low. In the land use structure of fallow land-shrubland-intercropping land-woodland (Fig. 4, T4), intercropping land had relatively high soil moisture content at $13.71 \%$. A terrace for gentle slope and the intercropping system for the improvement of soil physical properties may result in more water infiltrating into soil. In the fallow land-shrubland-cropland-orchard structure (Fig. 4, T5), the terraces softened the slope degree and encouraged infiltration whose average value of soil moisture was $15.2 \%$. Although the orchard was located in foot slope, its moisture was a low value of $12.67 \%$ in comparison with the croplands because of fruit trees' demand for more water in growing and anthesis period. Soil moisture contents were $12.21 \%$ and $9.67 \%$ in the fallow land and shrubland, respectively.

We further explored the relationships between soil physical properties and moisture variability along the slope by means of particle size distribution and bulk density. The particle distribution is highly variable along slope, and the slope position does not determine the particle distribution at $0-20 \mathrm{~cm}$. Bulk density is also variable and does 

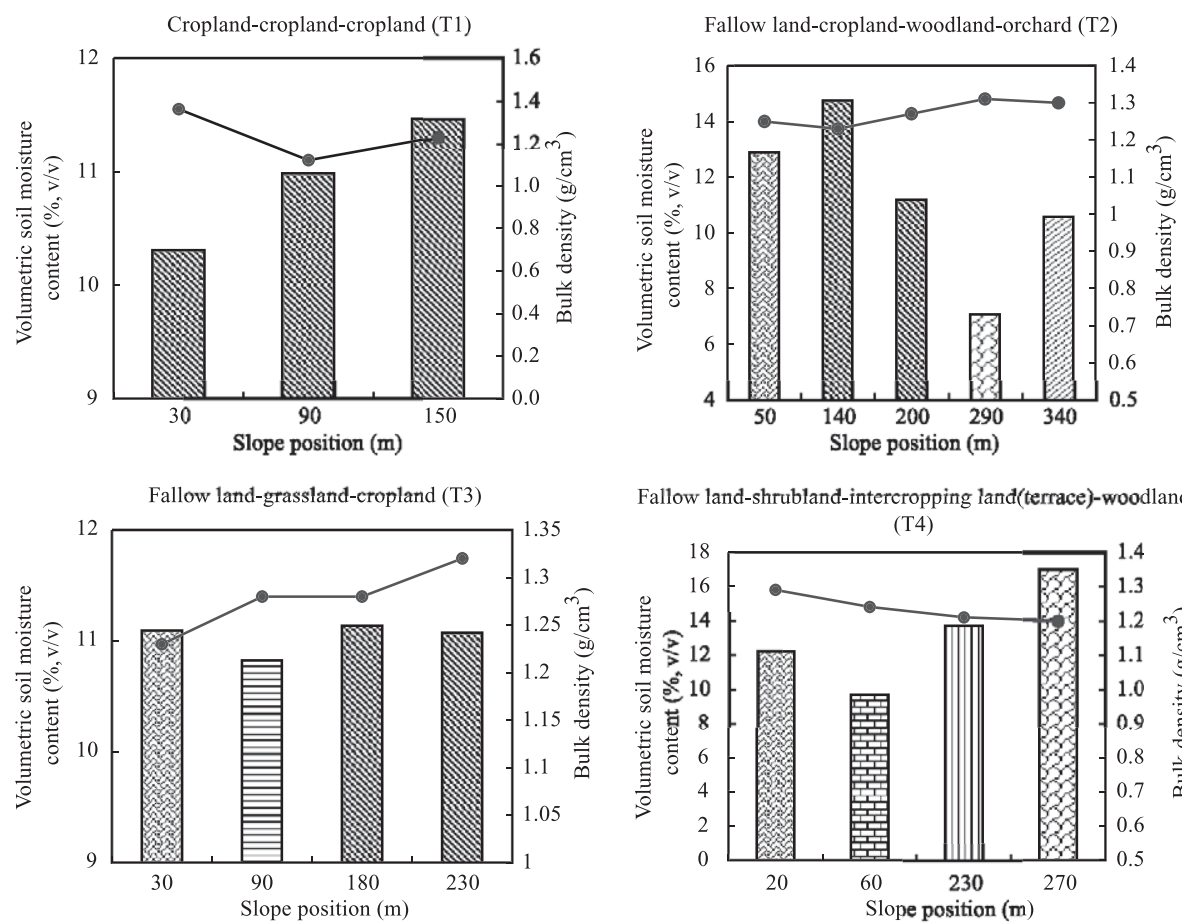

Fallow land-shrubland-intercropping land(terrace)-woodland

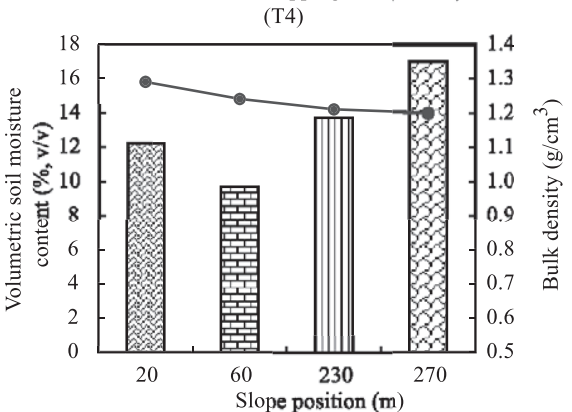

Fallow land-shrubland-cropland(terrace)-
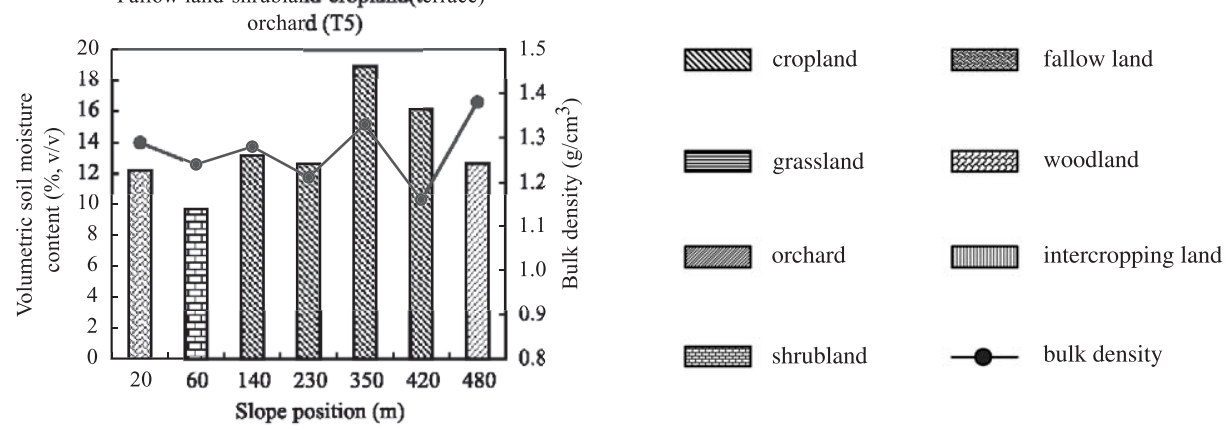

Fig. 4. The distribution of soil moisture contents on five land use structures. Also shown is the bulk density ( $\mathrm{g} /$ $\left.\mathrm{cm}^{3}\right)$.

not show any relationship with the slope (see Fig. 4). These irregular changes, in turn, cause the great soil moisture variability. For example, although the cropland located at the foot of a slope and showed higher bulk density $\left(1.32 \mathrm{~g} / \mathrm{cm}^{3}\right)$, its moisture content was close to cropland with low bulk density $\left(1.23 \mathrm{~g} / \mathrm{cm}^{3}\right)$ on the upslope (Fig. 4, T3). Again, due to lower bulk density $\left(1.20 \mathrm{~g} / \mathrm{cm}^{3}\right)$ which favours the water infiltration into the soil, the woodland in the downslope position exhibited the highest soil moisture content (Fig. 4, T4). 


\section{Discussions}

\subsection{Mechanism for controls on soil moisture variability at the Danangou catchment}

Because precipitation is the sole source for soil moisture in our study area, precipitation and evapotranspiration jointly control soil moisture level (Van den Elsen et al., 2003). Land uses can give rise to differences in evapotranspiration and soil physical properties (Table 1) that influence the soil moisture. The seasonal dynamics in mean soil moisture within $0-70 \mathrm{~cm}$ for seven land uses loosely mirrored precipitation amounts. During May, June, July and August, soil moisture was relatively uniform across the catchment. It is likely due to the fact that frequent rains limited differences in evapotranspiration and soil properties of land uses. However, high spatial variance in mean soil moisture existed during September and October. In addition, the difference in peak value of soil moisture between woodland and intercropping land and other four land uses may be explained by differences in soil physical attributes and the buffer effects of ground cover.

The profile soil moisture changes of seven land uses were classified into three types consisting of increasing, decreasing and waving types (Fig. 3). Clearly, differences in distribution of roots and soil physical properties would contribute to the difference in the variability of profile soil moisture.

Along the slope, soil properties and topography continue to jointly influence moisture, and the impact of topography on soil moisture was apparent, especially for single land use distribution on a slope (Fig. 4, T1). However, multiple land uses disturb this influence (Fig. 4, T2-T5). Results of the particle distribution and bulk density indicated that they do not exhibit a systematic trend along the slope under the effects of land use. These would result in the fluctuations in soil moisture from the top to foot of the slope.

\subsection{Implications for modeling}

Soil moisture content is a state variable which is either simulated or required as input for some hydrological models such as a distributed model. It is important that a watershed is subdivided into homogeneous areas in hydrological response terms of 'hydrological response unit' (Flugel, 1995). These factors influencing soil moisture are major references in determining the hydrologic response unit. Hawley et al. (1983) reported that a knowledge of the topographic variation of the surface (especially in relative elevation) might be used as a substitute for soil moisture in determining areas of homogeneous hydrological response. But application to multiple land uses on a slope and catchment scale is problematic because multiple land uses would increase soil moisture variability. Our results from the Loess Plateau of China demonstrated that soil moisture changes differed in land uses and five land use structures (Figs. 3 and 4). In comparison with the cropland, orchard and intercropping land, mean soil moisture in the shrubland was significantly different during the study period (Table 2). The profile soil moisture of seven land uses exhibited three types (Fig. 4) which implied a different potential for infiltration. In addition, the effects of land use pattern on soil moisture distribution were complex (Fig. 4). The average soil moisture content on a slope ranged from 10.92\% (Fig. $4, \mathrm{~T} 1$ ) to $13.62 \%$ (Fig. 4, T5). Therefore, the homogenous hydrological unit is not only 
influenced by the topographical variations, but also by the land use and its patterns. Averaging soil moisture values over the slope or neglecting the profile feature of the land use for modeling may lead to error.

\subsection{Implications for land management}

Soil erosion and shortage of soil moisture seriously restrict land productivity in semiarid environments also involving the Loess Plateau of China. Therefore, how to control soil erosion and improve soil moisture for plant is a key issue of land management in this region.

The hydrological response unit is an area with similar hydrological response. Because the principal runoff generating mechanism is rainfall intensity exceeding soil infiltration capacity in this region, for a specific hydrological response unit, it may exhibit a threshold value determined by the infiltration intensity (Liu and Kang, 1999) for runoff to occur. Overland flow from a unit will only occur when the infiltration threshold is exceeded for a specific storm. However, at a slope scale, the potential surface runoff areas are dependent on the hydrological response units' arrangement. When there are differences in initial soil moisture and infiltration rates between these close areas, the time of surface runoff beginning (Zhang and Liang, 1995) is different and runoff-producing areas are spatially isolated. So surface runoff of a slope will be reabsorbed by the surrounding drier or higher infiltration rate areas which act as sinks for overland flow and transported sediments, and the runoff from the top to bottom of slope will not occur. At a catchment scale, widespread runoff and erosion must overcome the spatial arrangement and threshold values of hydrological response units at small scales and requires prolonged or larger magnitude storms. Therefore, creating a mosaic pattern of areas with contrasting hydrological responses may be an effective management strategy in runoff and erosion control (Fitzjohn et al., 1998). However, land uses can produce changes in soil physical attributes and evapotranspiration to result in infiltration changes. Moreover, our results also indicate that soil moisture of seven land use types exhibited differences in temporal dynamics and profiles (Figs. 2 and 3, and Table 2). So, Mosaic patterns can be achieved by land use arrangement.

For a heavy storm, the rainfall intensity exceeds the majority of infiltration thresholds of the individual hydrological response unit, and larger areas will be contributing to surface runoff regardless of the spatial distribution of land use. In this situation, the differences in initial soil moisture and infiltration rate may not be essential. However, initial soil moisture (Zhang and Liang, 1995; Andrew et al., 1998) and infiltration rate (Liu and Kang, 1999) are important in the processes producing runoff in many situations. The similar land uses along a slope showed an increase in soil moisture from the top to foot of the slope (Fig. 4, T1, T3), their profile soil moisture exhibited increasing type (Fig. 4). Consequently, they had similar infiltration rate (Jiang, 1997). This may easily give rise to source areas producing runoff that is connected and produces continuous hydrological pathways. At last, the possibility for widespread runoff and erosion over the slope would greatly increase. In addition, due to similar harvesting period for crops, the soils exposed are weakly resistant to water and wind, and are often highly erodible with severe erosion occurring over very short time spans. We can establish buffer zones (different vegetation 
strips) for reabsorbing the runoff and trapping sediments from the upslope (Morgan, 1992) in this land use structure. Contrasting hydrological responses along a slope, resulting from initial soil moisture (Fig. 3) and infiltration rate (Li et al., 1995; Kang et al., 1996), determine the differences in runoff from different land uses. There is no connectivity between runoff producing areas on a slope to minimize runoff and erosion in many situations. For example, the spatial variations of erosion intensity were generally controlled by topography and exhibited an increase trend from the top to bottom of a slope (Tang, 1999) in this area. However, several researchers found by field survey and modeling that rational land use arrangement would disturb this relationship and showed patch distribution of erosion intensity in relation to land use (e.g. Jiang et al., 1996; Dong et al., 1998). Based on our field survey of runoff in 1999, the land use structure of cropland-cropland-cropland (T1) produced the most amount of runoff implying more likely continuous runoff over a slope, the fallow land-grassland-cropland structure followed, and while the fallow land-shrubland-intercropping land-woodland structure had the least runoff and thus least soil erosion than any others (Wang, 2000). Therefore, more attention should be paid to the selection and arrangement of land use on a slope and catchment scale (Fu et al., 2000) based on spatial soil moisture patterns and ecological properties of plant species. Seeding drought-tolerated shrubs and grasses on upper slope, benching terraces for crops and intercropping systems on middle slopes and planting trees (fruit trees) on the downslope and bottom of gullies, may be a more appropriate land use structure for soil and water conservation in the study area.

Soil moisture is one of the primary limiting factors for plant growth in semiarid areas. Some measures such as terracing aim to encourage infiltration for increasing soil moisture content. Our results indicated that the mean soil moisture content in terraces for cropland $(15.2 \%)$ was higher than that $(11.1 \%)$ on slope cropland. The intercropping system, exerting mutual benefits for tree and crop, is also a better tillage system in semiarid areas (Kiepe, 1995). In addition, 0-25 cm soil moisture varied greatly and was strongly affected by precipitation and evaporation (Table 3), so selecting a growing period for crops similar to the rainy season can improve the viability of rainfall.

\section{Conclusions}

Variability in seasonal dynamics and profile changes of soil moisture in relation to land use and its pattern was studied at 26 locations and five land use structures at the Danangou catchment on the Loess Plateau of China. Land use and its spatial distribution pattern also contribute to the soil moisture variations together with rainfall, topography and soil properties. The temporal dynamics of soil moisture for seven land uses showed three peaks and three troughs during growing season. Lag influence on soil moisture was found in the woodland and intercropping land. The influence of the shrubland on mean soil moisture content during the study period was significantly different in comparison with the cropland, orchard and intercropping land. Three types for profile soil moisture variations in seven land uses were classified. Increasing type included the cropland, fallow land, intercropping land and grassland. Waving type had the woodland and orchard. The shrubland was present as a decreasing type. Soil moisture variability differed in five land use structures, which implied 
that different hydrological response unit concerning soil moisture along a slope could be created by land use arrangement. This pattern with contrasting hydrological response unit such as the fallow land-shrubland-intercropping land-woodland structure would lead to discontinuous runoff over a slope and thus control soil erosion better.

\section{Acknowledgements}

The project was supported by the INCO-DC programme of European Commission (Contract No. ERBIC18CT970158) and the National Natural Science Foundation of China (Contract No. 49725101 and 90102018). The authors wish to acknowledge the members of project team for measuring the soil moisture in the field.

\section{References}

Anderson, M.G., Burt, T.P., 1978. Toward a more detailed field monitoring of variable source areas. Water Resources Research 14, 1123-1131.

Anderson, M.G., Kneale, P.E., 1980. Topography and hillslope soil water relationships in a catchment of low relief. Journal of Hydrology 47, 115-128.

Andrew, W.W., Günter, B., Rodger, B.G., 1998. Geostatistical characterisation of soil moisture patterns in the Tarrawarra catchment. Journal of Hydrology 205, 20-37.

Bárdossy, A., Lehmann, W., 1998. Spatial distribution of soil moisture in a small catchment: Part 1. Geostatistical analysis. Journal of Hydrology 206, 1-15.

Barling, R.D., Moore, I.D., Grayson, R.B., 1994. A quasi-dynamic wetness index for characterizing the spatial distribution of zones of surface saturation and soil water content. Water Resources Research 30, 1029-1044.

Bell, K.R., Blanchard, B.J., Schmugge, T.J., Witczak, M.W., 1980. Analysis of surface moisture variations within large field sites. Water Resources Research 16 (4), 796-810.

Burt, T.P., Butcher, D.P., 1985. Topographic controls of soil moisture distribution. Journal of Soil Science 36, $469-486$.

Chen, L.D., Wang, J., Fu, B.J., Qiu, Y., 2001. Land use change in a small catchment of northern Loess Plateau, China. Agriculture, Ecosystems and Environment 86 (2), 163-172.

Dong, R., Zhu, X., He, Z., Wan, T., Wang, X., 1998. Laws of soil erosion in loess hilly and Gully region of Dingxi prefecture. Bulletin of Soil and Water Conservation 18 (3), 1-15 (in Chinese).

Editorial Committee, 1996. Soil Physical and Chemical Analysis and Description of Soil Profiles. Standards Press of China, Beijing, pp. 5-151 (In Chinese).

Famiglietti, J.S., Rudnicki, J.W., Rodell, M., 1998. Variability in surface soil content along a hillslope transect: rattlesnake Hill, Texas. Journal of Hydrology 210, 259-281.

Fitzjohn, C., Ternan, J.L., Williams, A.G., 1998. Soil moisture variability in a semi-arid gully catchment: implications for runoff and erosion control. Catena 32, 55-70.

Flugel, W.A., 1995. Delineating hydrological response units by geographical information system analyses for regional hydrological modelling using PRMS/MMS in the drainage basin of the river Brol, Germany. Hydrological Processes 9, 423-436.

Fu, B.J., 1989. Soil erosion and its control in the Loess Plateau of China. Soil Use and Management 5, 76-82.

Fu, B., Gulinck, H., 1994. Land evaluation in area of severe erosion: the Loess Plateau of China. Land Degradation and Rehabilitation 5 (1), 33-40.

Fu, B.J., Chen, L.D., Ma, K.M., Zhou, H.F., Wang, J., 2000. The relationships between land use and soil conditions in the hilly area of the Loess Plateau in northern Shaanxi, China. Catena 36, 69-78.

Gomez-Plaza, A., Alvarez-Rogel, J., Albaladejo, J., Castillo, V.M., 2000. Spatial patterns and temporal stability of soil moisture across a range of scales in a semi-arid environment. Hydrological Processes 14, 1261-1277. 
Grayson, R.B., Western, A.W., 1998. Towards areal estimation of soil water content from point measurements: time and space stability of mean response. Journal of Hydrology 207, 68-82.

Grayson, R.B., Moore, I.D., McMahon, T.A., 1992. Physically based hydrologic modeling: 1. A terrain-based model for investigative purposes. Water Resources Research 28, 2639-2658.

Hawley, M.E., Jackson, T.J., McCuen, R.H., 1983. Surface soil moisture variation on small agricultural watersheds. Journal of Hydrology 62, 179-200.

Jiang, D., 1997. Soil Erosion and Control Models in the Loess Plateau. Water Resources Press, Beijing (In Chinese).

Jiang, Z., Wang, Z., Liu, Z., 1996. Quantitative study on spatial variation of soil erosion in a small watershed in the loess hilly region. Journal of Soil Erosion and Soil and Water Conservation 2 (1), 1-9 (in Chinese).

José, M.F., Francisco, L., Julia, M., Asunción, R., 1995. Land use and soil-vegetation relationships in a Mediterranean ecosystem: El Ardal, Murcia, Spain. Catena 25, 153-167.

Kang, S., Zhang, S., Nie, G., Shi, S., Gou, Z., Qi, Z., Cui, X., 1996. Research on soil infiltration distribution of Aobao water basin in Inner Mongolia. Journal of Soil Erosion and Soil and Water Conservation 2 (2), 38-46 (in Chinese).

Kiepe, P., 1995. No runoff, no soil loss: soil and water conservation in hedgerow barrier systems. Tropical Resource Management Papers. Wageningen Agricultural University, Wageningen, pp. 1-42.

Knapp, A.K., Fahnestock, J.T., Hamburg, S.P., Statland, L.B., Seastedt, T.R., Schimel, D.S., 1993. Landscape patterns in soil-water relations and primary production in tallgrass prairie. Ecology 74, 540-549.

Le Roux, X., Bariac, T., Mariotti, A., 1995. Spatial partitioning of the soil water resource between grass and shrub components in a West African humid savanna. Oecologia 104, 147-155.

Li, G., Luk, S.H., Cai, Q.G., 1995. Topographic zonation of infiltration in the hilly loess region, North China. Hydrological Processes 9, 227-235.

Liu, X., Kang, S., 1999. Some developments and review of rainfall-infiltration-runoff yield research. Bulletin of Soil and Water Conservation 19 (2), 57-62 (in Chinese).

Messing, I., Chen, L.D., Hessel, R., 2003. Soil conditions in a small catchment on the Loess Plateau in China. Catena 54, 45-58. (doi:10.1016/S0341-8162(03)00056-0)

Morgan, R.P.C., 1992. Soil conservation options and in the U.K. Soil Use and Management 8, 176-180.

Qiu, Y., Fu, B.J., Wang, J., Chen, L.D., 2001. Soil moisture variation in relation to topography and land use in a hillslope catchment of the Loess Plateau, China. Journal of Hydrology 240, 243-263.

Qiu, Y., Fu, B.J., Wang, J., Chen, L.D., 2003. Spatio-temporal prediction of soil moisture content using multiple-linear regression in a small catchment of the Loess Plateau, China. Catena, 54, 173-195. (doi:10.1016/S0341-8162(03)00064-X)

Ried, I., 1973. The influence of slope orientation upon the soil moisture regime and its hydrogeomorphological significance. Journal of Hydrology 19, 309-321.

Sala, O.E., Lauenroth, W.K., Parton, W.J., 1992. Long-term soil water dynamics in the shortgrass steppe. Ecology 73 (4), 1175-1181.

Song, G.Q., Li, L.T., Guo, F.G., Zhao, M.L., 1989. Land classification of experiment and exemplary areas on the Loess Plateau. Memoir of Northwestern Institute of Soil and Water Conservation, Academia Sinica and Ministry of Water Resources 10,1-13 (in Chinese).

SPSS, 1993. SPSS for widows base system user's guide release 6.0. Marija J.Norusis/SPSS.

Stolte, J., Liu, B.Y., Ritsema, C.J., Van den Elsen, H.G.M., Hessel, R., 2003. Modelling water flow and sediment processes in a small gully system on the Loess Plateau in China. Catena 54, 117-130. (doi:10.1016/S0341-8162(03)00060-2)

Tang, K., 1999. Characteristics and perspectives on scientific discipline of soil erosion and soil and water conservation in China. Research of Soil and Water Conservation 6 (2), 2-7 (in Chinese).

Vachaud, G., Passerat de Silans, P., Balabanis, P., Vauclin, M., 1985. Temporal stability of spatially measured soil water probability density function. Soil Science Society of America Journal 49, 822-828.

Van den Elsen, H.G.M., Hessel, R., Liu, B.Y., Trouwborst, K.O., Stolte, J., Ritsema, C.J., Blijenberg, H., 2003. Discharge and sediment measurements at the outlet of a watershed on the Loess Plateau of China. Catena 54, 147-160. (doi:10.1016/S0341-8162(03)00062-6)

Wang, J., 2000. Study on the effects of land use and its patterns on ecological processes in the hilly area of Loess 
Plateau of China. PhD dissertation of Research Center for Eco-environmental Sciences, pp. 136-144 (In Chinese).

Wang, M.B., Li, H.J., 1989. Study on soil water ecological environment of artificial Caragana Korshinskii bushwood. Memoir of Northwestern Institute of Soil and Water Conservation Academia Sinica and Ministry of Water Resources 10, 155-160 (in Chinese).

Wang, J., Fu, B.J., Qiu, Y., Chen, L.D., Wang, Z., 2001. Geostatistical analysis of soil moisture variability on Danangou catchment of Loess Plateau, China. Environmental Geology 41, 113-120.

Wang, J., Fu, B.J., Qiu, Y., Chen, L.D., 2003. Analysis on soil nutrient characteristics for sustainable land use in Da Nangou catchment of the Loess Plateau, China. Catena 54, 17-29. (doi:10.1016/S0341-8162(03)00054-7)

Zhang, G., Liang, Y., 1995. Study on runoff beginning time of artificial grassland in loess hilly region. Journal of Soil and Water Conservation 9 (3), $78-83$ (in Chinese).

Zhu, Z.C., 1993. The main characteristics of the vegetation and its impact on the soil essence in the Loess Plateau of northern Shaanxi province. Acta Phytoecologica et Geobotanica Sinica 17 (3), 280-286 (in Chinese). 